\title{
Morphological variation and new distributional records of Rhadinella dysmica (Serpentes: Dipsadidae), with comparisons with other dark-colored congeners
}

\footnotetext{
Ricardo Palacios-Aguilar, ${ }^{1,5,6}$ Rufino Santos-Bibiano, ${ }^{2,5,6}$ Jonathan Atwood Campbell, ${ }^{3}$ and Elizabeth Beltrán-Sánchez ${ }^{4}$

${ }^{1}$ Universidad Nacional Autónoma de México, Facultad de Ciencias, Museo de Zoología Alfonso L. Herrera. Apartado postal 70-399, México D.F., CP 04510, Mexico. E-mail: ricardopalaciosaguilar@gmail.com.

${ }^{2}$ Universidad Nacional Autónoma de México, Instituto de Biología, Departamento de Zoología, Laboratorio de Herpetología 2. Apartado postal 70515, 04510 Coyoacán, México, D. F., México.

${ }^{3}$ University of Texas at Arlington, Department of Biology, 76019 Arlington, Texas, USA.

${ }^{4}$ Universidad Autónoma de Guerrero, Área de Ciencias Naturales, Instituto de Investigación Científica, Interior del Jardín Botánico. C.P. 39000, Chilpancingo, Guerrero, Mexico.

${ }^{5}$ Universidad Nacional Autónoma de México, Posgrado en Ciencias Biológicas, Unidad de Posgrado. Edificio A, 1er. Piso, Circuito de Posgrados, Ciudad Universitaria, C.P. 04510, Cuidad de México, Mexico.

${ }^{6}$ Instituto para el Manejo y Conservación de la Biodiversidad (INMACOB) A. C., Calle Durango 23, Colonia José Vasconcelos, C. P. 39047, Chilpancingo de los Bravo, Guerrero, Mexico.
}

\begin{abstract}
Morphological variation and new distributional records of Rhadinella dysmica (Serpentes: Dipsadidae), with comparisons with other dark-colored congeners. Small, secretive snakes comprise an important part of the herpetofauna of the Neotropics and yet most species are known from a handful of specimens due to their habits and relatively inaccessible localities. The Mexican endemic Rhadinella dysmica is the westernmost species of the genus and was described based on a single adult female. Herein we provide information on new specimens, including their morphological variation and hemipenial structure, expand the known geographic range for the species, and comment on the morphological similarities of the "dark-colored" species of the genus.
\end{abstract}

Keywords: Endemic species, extended diagnosis, Guerrero, hemipenial morphology, snakes.

\section{Resumo}

Variação morfológica e novos registos de distribuição de Rhadinella dysmica (Serpentes: Dipsadidae), com comparações com outros congêneres de coloração escura. Serpentes de pequeno porte e com hábitos secretivos constituem uma parte importante da herpetofauna dos Neotrópicos, mas a maioria das espécies é conhecida a partir de poucos exemplares devido a seus hábitos e localidades 
relativamente inacessíveis. A serpente endémica mexicana Rhadinella dysmica é a espécie mais ocidental do género, tendo sido descrita com base em uma única fêmea adulta. Fornecemos aqui informações sobre novos espécimes, incluindo a sua variação morfológica e da estrutura do hemipênis, expandimos a distribuição geográfica conhecida para a espécie e discutimos as similaridades morfológicas das espécies "de coloração escura" do gênero.

Palavras-chave: diagnose estendida, espécie endêmica, Guerrero, morfologia hemipeniana, serpentes.

\section{Introduction}

Small, secretive snakes from the Neotropics have habits that limit their study, and knowledge on their biology remains fragmentary in many cases. Low population densities, secretive life styles, small geographic ranges, and specialized microhabitats have been proposed as the main limiting factors in studying them (Myers 2003). The genus Rhadinella contains a group of 20 species of small, slender snakes (Campillo et al. 2016, McCranie 2017, Ariano-Sánchez and Campbell 2018), collectively ranging from Guerrero and Veracruz, Mexico, southwards to western Panama (Myers 1974, Campillo et al. 2016). Members of the genus tend to be highly secretive and some species remain known only from their holotypes (Campbell 2015, Campillo et al. 2016, Ariano-Sánchez and Campbell 2018). Rhadinella dysmica Campillo, DávilaGalavíz, Flores-Villela and Campbell, 2016 is the westernmost member of the genus and was described from a single female specimen from near Cueva Tepozonales in central Guerrero, Mexico (Campillo et al. 2016). Recent fieldwork by personnel from the Universidad Autónoma de Guerrero and Universidad Nacional Autónoma de México has led to the collection of new specimens of this species, including the first known males. Here we illustrate the hemipenis, report on the variation of this species, and compare it with other dark-colored congeners $[R$. donaji Campbell, 2015, $R$. dysmica, $R$. pilonaorum (Stuart, 1954), R. schistosa Smith, 1941, $R$. posadasi (Slevin, 1936), and $R$. xerophila Ariano-Sánchez and Campbell, 2018].

\section{Materials and Methods}

We examined specimens in the herpetological collections of the Escuela Nacional de Ciencias Biológicas, Instituto Politécnico Nacional (ENCB) and the Museo de Zoología "Alfonso L. Herrera, Facultad de Ciencias, Universidad Nacional Autónoma de México (MZFC). One specimen from the collection of the Laboratorio Integral de Fauna Silvestre at the Universidad Autónoma de Guerrero was examined, and subsequently deposited at MZFC-UNAM. Two live specimens were collected by the authors in June 2018 and later deposited at MZFC. Another adult snake collected by a field team on June 2020 was offered to us for examination, but this specimen was lost during transportation. However, digital photographs of this specimen are available for study.

All measurements were taken with dial calipers and rounded to the nearest $0.1 \mathrm{~mm}$, except for snout-vent length (SVL) and tail length, which were measured with a metal ruler and rounded to the nearest millimeter. Ventral scales were counted according to Dowling (1951), and segmental counts are as defined by Savage and Lahanas (1991). Hemipenial preparations were made following the procedures of Myers and Cadle (2003) and Zaher and Prudente (2003), as modified by Smith and Ferrari-Castro (2008). Hemipenial terminology follows Dowling and Savage (1960) and Myers and Campbell (1981). Maxillary dentition was observed in situ by making a longitudinal incision between the supralabials and the maxillary arch, removing tissues and counting teeth and empty sockets. 


\section{Results}

Four specimens, two males and two females, plus photos of a fifth specimen, were examined (Table 1).

\section{Expanded Definition Based on Additional Material}

A small dipsadid snake (166-265 mm SVL), with a long tail $(33.1 \%$ of SVL in males, $33.7 \%$ in females); head slightly distinct from neck; snout moderately elongated, broadly rounded in dorsal profile; rostral not extending between internasals; cephalic plates arranged in regular colubrid fashion; internasals paired, prefrontals paired, broad median frontal, supraoculars paired, narrow, and parietals elongate, paired; nuchals 6-7; nasal divided; postnasal contacting prefrontal, loreal and supralabials 1-2; loreal single, broader than high, more than half length of eye; preocular one, subpreocular absent; postocular one; temporal scales $1+2$, anterior temporal above supralabials 5-6; supralabials $7 / 7,3-4$ entering the orbit; eye small, with a round pupil; infralabials 9/9, first pair in broad contact with the posterior of mental, 1-4 in contact with anterior pair of chinshields; chinshields in two pairs, longer than wide, anterior pair slightly longer than posterior pair; posterior pair of chinshields separated for posterior part of their length by two gulars; mental groove present; dorsal scales smooth, in 17-17-17 rows, apical pits usually absent but present at midbody in one adult male (MZFC 31981); ventrals $155-172$ (155-165 in males, 169-172 in females); cloacal plate divided; subcaudals paired, 105-108 (105 in one juvenile male, 108 in one juvenile female; Table 1); segmental counts 263-274 (274 in one male, 263 in one female); maxillary teeth 10-12, increasing progressively in size posteriorly. Variation in selected morphological characters is summarized in Table 1.

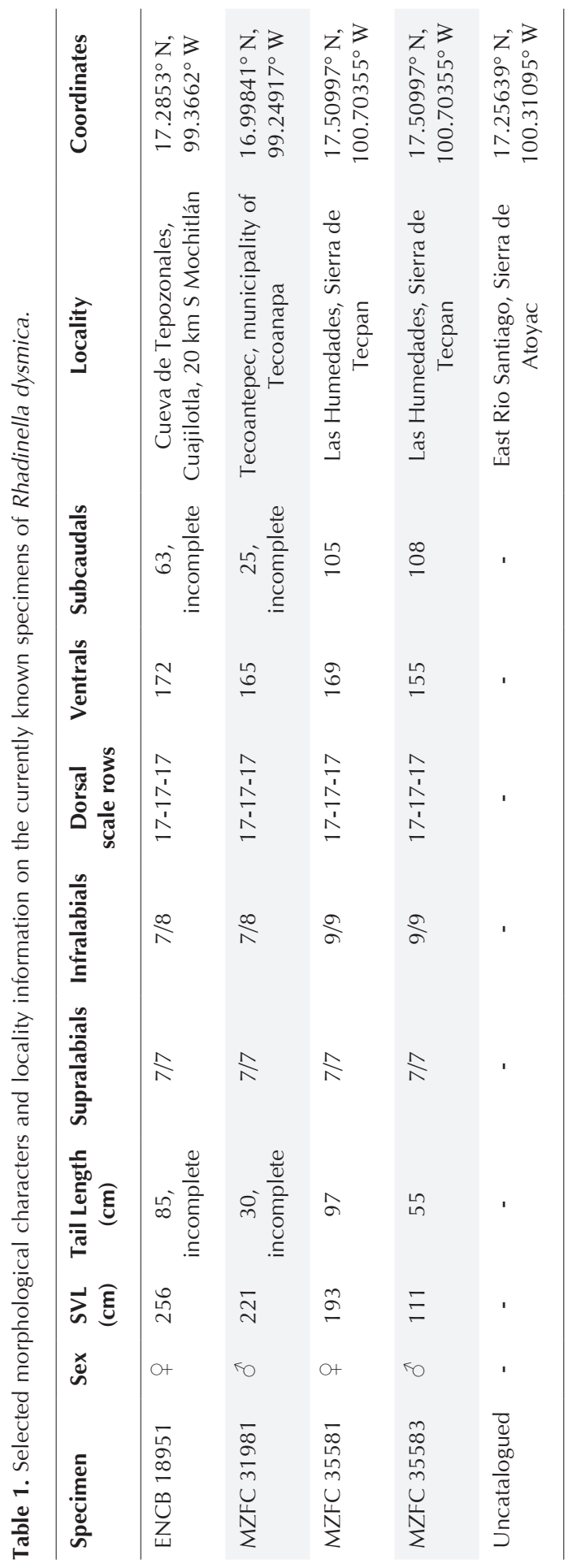

Phyllomedusa - 20(2), December 2021 


\section{Coloration}

In most specimens dorsal surfaces of the head, body, and tail are dark gray. In some specimens subtle darker stripes are visible against the background (Figure 1), but these became obscured with preservation. A pale nuchal collar encompasses 3-31/2 dorsal scale lengths laterally and narrows to two scales middorsally, occasionally dark pigment is present at the narrowest point. The nuchal scales bordering the parietals are creamy white or white with yellow margins; the collar encompasses the borders of the parietals, secondary temporals, the uppermost part of the primary temporals and fades towards the venter. Pale markings are present on a few supralabials (frequently in 5-7), but in the holotype these markings are present on all supralabials. The mentals have dark brown markings; the infralabials have irregular dark brown vertical streaks; the venter is creamy white with scattered brown markings; the subcaudals are dingy white with dark brown borders.

Coloration of the new specimens is mostly in agreement with the holotype, except for a specimen from Río Santiago that exhibits dark brown dorsal surfaces of the body, tail and head, and an orange-pink pale nuchal collar that encompasses not only the posterior of the
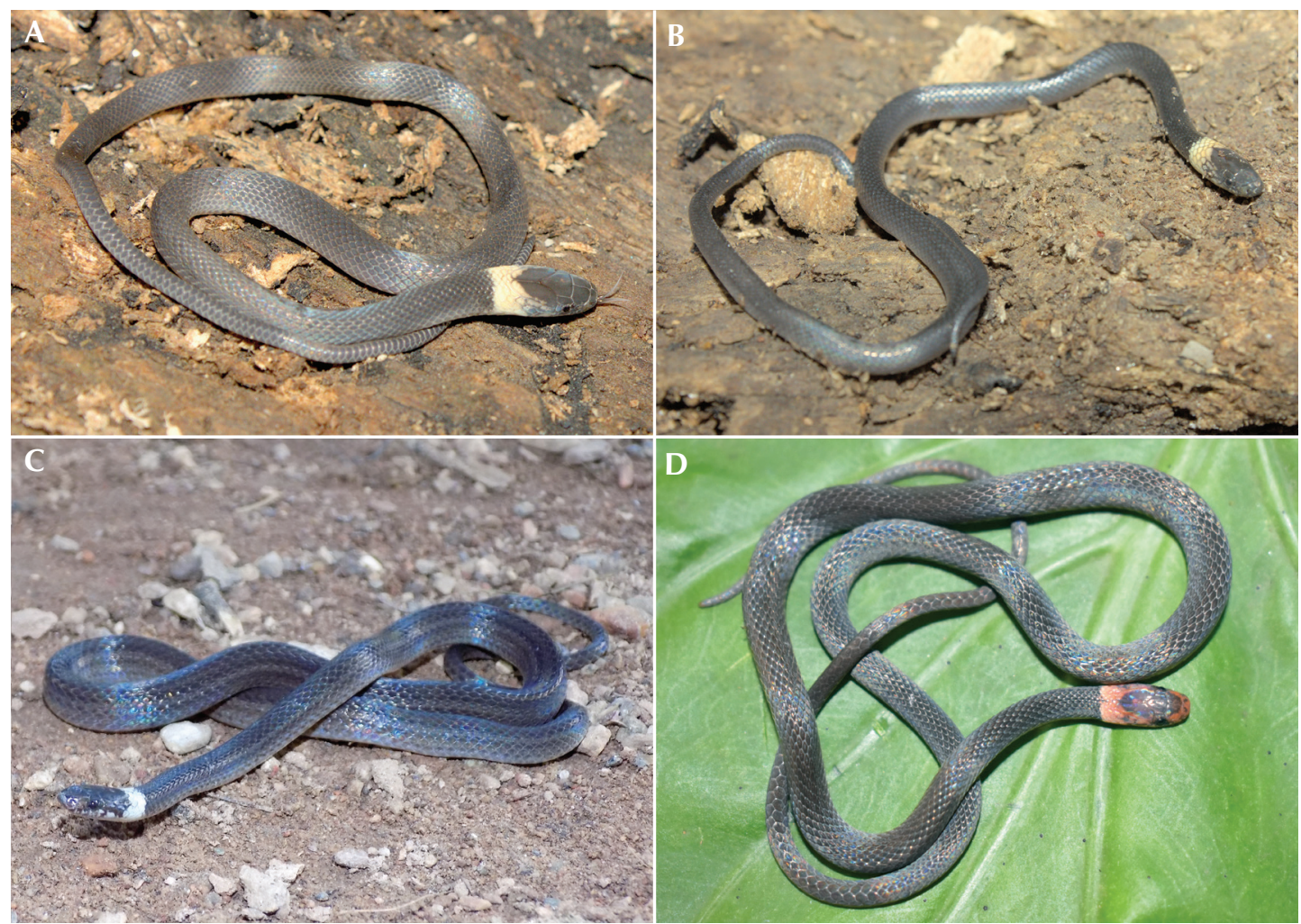

Figure 1. Coloration variation in Rhadinella dysmica. (A-B) Specimens from Ejido Las Humedades, Sierra de Tecpan (MZFC 35583 and 35581, respectively). (C) holotype from near Cuajilotla exhibiting dark striping in life (ENCB 18951). (D) specimen from east of Río Santiago, Sierra de Atoyac (not vouchered). All localities are in Guerrero, Mexico. 
head, but also the anterior part of the snout, including the rostral, internasals and distal margins of the prefrontrals (Figure 1). This specimen was lost, so further comparisons of this "morphology" require the procurement of additional material.

\section{Hemipenis}

Both hemipenes of MZFC 31981 were everted at the time of preservation and the left organ was removed and prepared with colored petroleum jelly (Figure 2). The everted organ is slightly recurved, and the capitulum represents about one-third of the organ length. The retractor muscle reaches subcaudal 20 . The organ is very slightly bilobated, unicapitate, and spinose, with a centrolineal sulcus spermaticus bifurcating at about the middle of the organ and bellow the edge of the capitulum. On the sulcate side, the lower third of the organ is naked with two large basal hooks; the second third of the organ bears three rows of spines; and the uppermost third of the organ is covered by papillate calyces. These calyces cover the entire capitulum and an adjacent region of near the bifurcation of the sulcus spermaticus. On the asulcate side the rows of spines terminate near the center at the level of the second third of the organ; two large spines are present on the middle of the organ; the capitulum ornamentation is essentially the same as for the sulcate side (Figure 2). There are three conspicuous naked pockets on the hemipenis: one on the basal portion on one side of the hemipenis; one as an enlarged calyx at the lower edge of the capitulum on the asulcate and lateral view; and a large nude, concave space bellow the capitulum on the asulcate side, surrounded by numerous spines and a basal hook on the lowermost part (Figure 2).
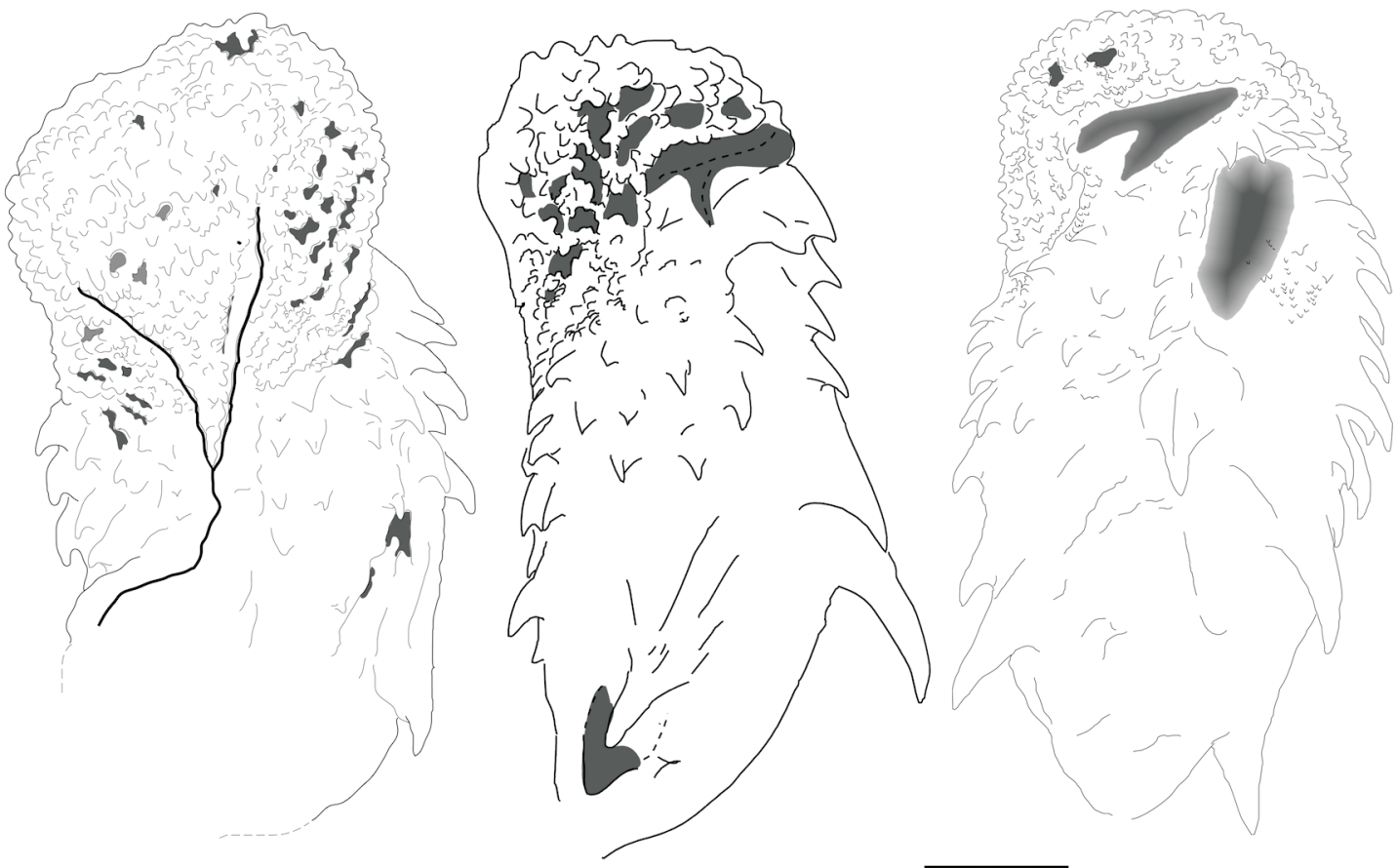

Figure 2. Hemipenis of the specimen MZFC 31981 in sulcate, lateral and asulcate view. Scale bar = $1 \mathrm{~mm}$. 


\section{Distribution, Habitat and Conservation}

As currently understood, the distribution of Rhadinella dysmica is restricted to central Guerrero at elevations from 430-725 m a.s.l., on the windward side of the Sierra Madre del Sur of Guerrero. Specifically, from the Sierra de Tecpan south-eastwards to the southern slopes of the Sierra de Mochitlán and the hills north of Tecoanapa near the Río Omitlán (Figure 3). All the above localities, including the type locality, are covered by tropical deciduous forest and those from the Sierra de Atoyac and Sierra de Tecpan are covered by tropical semi-evergreen forest.

The new specimens were obtained from Tecoantepec, $430 \mathrm{~m}$ a.s.1., municipality of Tecoanapa (MZFC 31981); east of Río Santiago, $725 \mathrm{~m}$ a.s.1., municipality of Atoyac de Álvarez (not vouchered); and Las Humedades, $675 \mathrm{~m}$ a.s.l. municipality of Tecpan de Galeana (MZFC 35581, 35583; Table 1), extending the known distribution $34 \mathrm{~km} \mathrm{SW,} 105.6$ and $150.8 \mathrm{~km} \mathrm{~W}$, respectively, from the type locality.

The specimens from Las Humedades (MZFC 35581,35583 ) were obtained during the rainy season on 19 June 2018 under rotting logs. The specimen from Rio Santiago (not vouchered) was found crossing a paved road at night after a moderate rain on 10 June 2020. The specimen from Tecoantepec (MZFC 31981) was found inactive under a rock during a rain on 04 October 2008. Campillo et al. (2016) reported finding the holotype near the entrance of a cave crawling on the ground on 17 July 2014. Similar to many small semifossorial snakes, it is possible that $R$. dysmica has a wider and more or less continuous

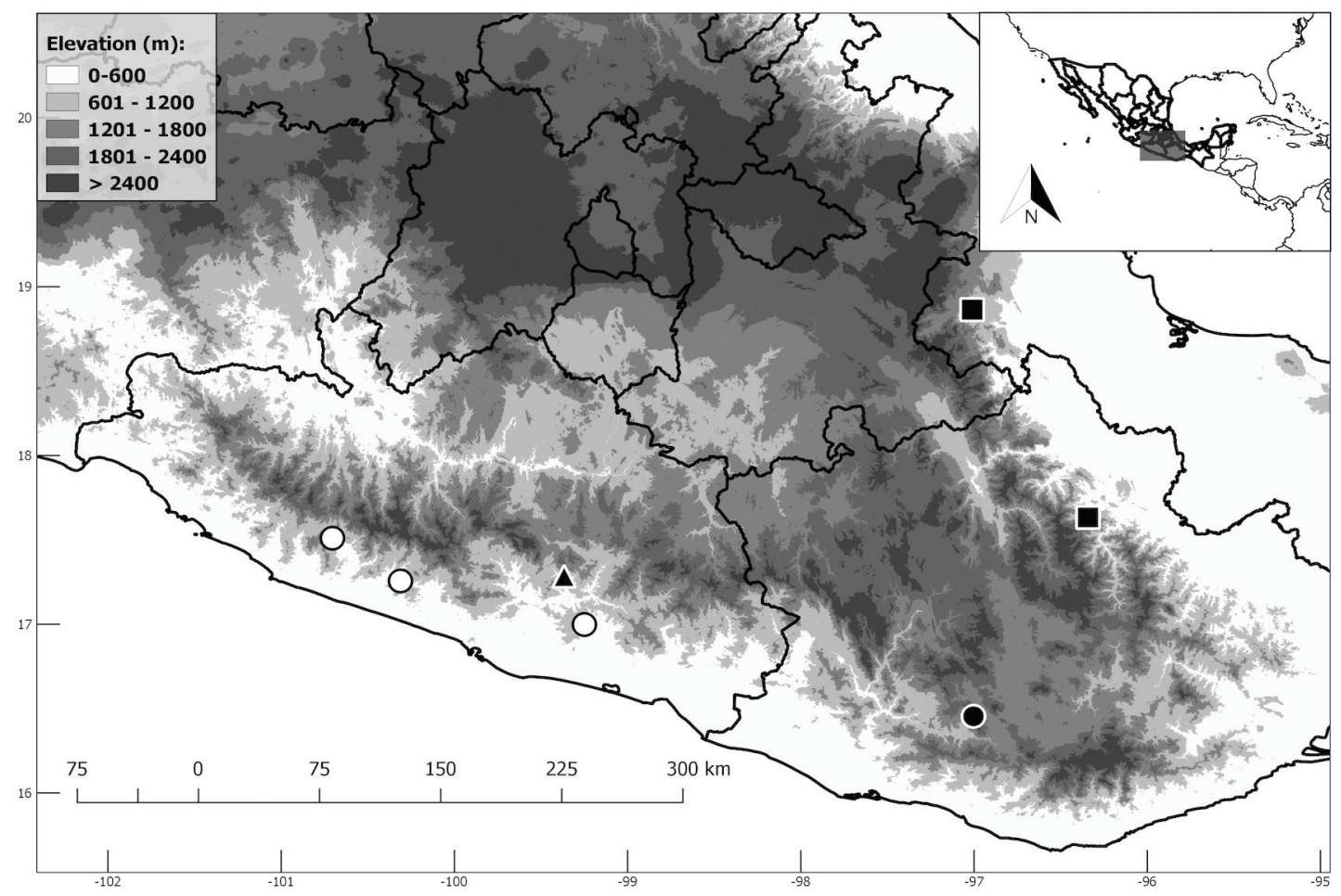

Figure 3. Geographic distribution of the species of Rhadinella west of the Isthmus of Tehuantepec. Rhadinella donaji: closed circle; R. dysmica: open circles, triangle represents type locality; R. schistosa: closed squares. 
distribution at moderate elevations of the Sierra Madre del Sur, but remains undetected due to its cryptic habits.

Despite the new specimens slightly increase the geographic distribution of $R$. dysmica, it is still considered restricted to Guerrero. Information on the natural history of the species is still limited, so we consider that the risk assessment proposed by Palacios-Aguilar and Flores-Villela (2018) using the system of Environmental Vulnerability Score (EVS) is appropriate, considering this species highly vulnerable (EVS, $6+8+2=16$ ), based mainly on its restricted ecological and geographical distribution.

\section{Discussion}

The new material reported herein provide a wider understanding of the morphological variation of $R$. dysmica. However, most species of Rhadinella are very similar in traditional diagnostic characters (see Campbell 2015, Campillo et al. 2016, and Ariano-Sánchez and Campbell 2018, for comparative tables). Most scutellation characters overlap between the darkcolored species, except for the relatively low number of subcaudals in $R$. schistosa.

Most of the diagnostic characters in the genus previously reported rely on color pattern. However, the color variation present in $R$. dysmica suggests that these characteristics of color pattern may not be as diagnostic as previously thought. Problems with assessing color pattern has been reported in other Dipsadidae taxa, for example in Apostolepis (Entiauspe-Neto et al. 2020), Atractus (Meneses-Pelayo and Passos 2019), Coniophanes (Palacios-Aguilar and Flores-Villela 2020), Geophis (Pavón-Vázquez et al. 2011) and hence, taxonomic decisions based solely on color patterns should be interpreted with caution. New species of Rhadinella have been described recently based on morphological differences, including color pattern (Campbell 2015, McCranie 2017). The color variation of $R$. dysmica might suggest that more than a single taxon is represented. However, we consider this unlikely because all specimens were found along a more-or-less continuous belt of tropical forests below $1000 \mathrm{~m}$ a.s.l., where no major geographic barriers exist. Rather, we consider that this is another case of color polymorphism, a feature that can vary individually, ontogenetically, geographically, and possibly sexually, in response to various selective pressures (e.g., Cox and Davis-Rabosky 2013).

Hemipenial features such as the bilobation, capitation, presence of basal pockets and spinulate calyces at least on one portion of the border of the capitulum have been reported previously on other members of the genus (Myers 1974, Holm and Cruz-Díaz 1994). However, the presence of a nude pocket on the capitulum and the asulcate side have been reported previously only on $R$. godmani (Günther, 1865) and $R$. lachrymans (Cope, 1870) (Myers 1974).

Most species of Rhadinella inhabit mesic habitats such as rain, cloud, and pine-oak forests (Campbell 2015), but recent explorations in Central America have discovered populations inhabiting seasonally dry forests (ArianoSánchez and Campbell 2018). Rhadinella dysmica seems to be present through an almost continuous belt of tropical deciduous and tropical semievergreen forests along the windward slope of the Sierra Madre del Sur of Guerrero.

The dark-colored species of Rhadinella might form a monophyletic supraspecific group of six species ( $R$. donaji, $R$. dysmica, $R$. pilonaorum, $R$. posadasi, $R$. schistosa, and $R$. xerophila), that can be defined by the absence of a subpreocular scale; dorsal scale rows17-17-17; ventral scales 136172; hemipenes bilobed (or, if single, with a divided retractor muscle); spinulate calyces on the edge of the capitulum; dorsal coloration dark gray, obscuring a hint of black longitudinal stripes on the body; and a white or cream collar. This group is distributed from Guerrero and Veracruz, Mexico, southwards to western El Salvador. An examination of larger samples for other morphological characters besides scutellation (hemipenes, maxillary dentition, osteology), in addition to assessment of molecular data would further elucidae the phylogenetic relationships of these under-studied Neotropical snakes. 


\section{Acknowledgments}

OFV and LMOO helped with specimen cataloguing at the MZFC-UNAM. A Rainforest Trust project (\#2-MX-571-19-1-a) provided to INMACOB A.C. with funding that allowed specimen acquisition in part. Eduardo Yesua Barrera Nava and HERP.MX provided additional specimens to study. RPA and RSB were funded by CONACyT graduate scholarships (CVU 857990 and 774550, respectively). Fieldwork conducted by us was conducted under permit numbers SGPA/DGVS/05850/14, SGPA/ DGVS/01205/17, and FAUT-0015 granted by the Secretaría de Medio Ambiente y Recursos Naturales (SEMARNAT).

\section{References}

Ariano-Sánchez, A. and J. A. Campbell. 2018. A new species of Rhadinella (Serpentes: Dipsadidae) from the dry forest of Motagua Valley, Guatemala. Zootaxa 4442: $338-344$.

Campbell, J. A. 2015. A new species of Rhadinella (Serpentes: Colubridae) from the Pacific versant of Oaxaca, Mexico. Zootaxa 3918: 397-405.

Campillo, G., L. F. Dávila-Galavíz, O. Flores-Villela, and J. A. Campbell. 2016. A new species of Rhadinella (Serpentes: Colubridae) from the Sierra Madre del Sur of Guerrero, Mexico. Zootaxa 4103: 165-173.

Cox, C. L. and A. R. Davis-Rabosky. 2013. Spatial and temporal drivers of phenotypic diversity in polymorphic snakes. American Naturalist 182: 40-57.

Dowling, H. G. 1951. A proposed standard method for counting ventrals in snakes. British Journal of Herpetology 1: 97-99.

Dowling, H. G. and J. M. Savage. 1960. A guide to the snake hemipenis: a survey of basic structure and systematic characters. Zoologica 45: 17-28.

Entiauspe-Neto, O. M., C. Koch, T. B. Guedes, and A. Tiutenko. 2020. Revisiting the taxonomic status of Apostolepis sanctaeritae, a forgotten Neotropical dipsadid snake. Salamandra 56: 329-341.

Holm, P. A. and G. A. Cruz-Díaz. 1994. A new species of Rhadinaea (Colubridae) from a cloud forest in northern Honduras. Herpetologica 50: 15-23.
McCranie, J. R. 2017. A new species of Rhadinella (Serpentes: Dipsadidae) from the Sierra de Agalta, Honduras. Mesoamerican Herpetology 4: 244-253.

Meneses-Pelayo, E. and P. Passos. 2019. New polychromatic species of Atractus (Serpentes: Dipsadidae) from the eastern portion of the Colombian Andes. Copeia 107: 250-261.

Myers, C. W. 1974. The systematics of Rhadinaea (Colubridae), a genus of New World snakes. Bulletin of the American Museum of Natural History 153: 1-262.

Myers, C. W. 2003. Rare snakes-Five new species from Eastern Panama: reviews on Northern Atractus and Southern Geophis (Colubridae: Dipsadinae). American Museum Novitates 3391: 1-47.

Myers, C. W. and J. A. Campbell. 1981. A new genus and species of colubrid snake from the Sierra Madre del Sur of Guerrero, Mexico. American Museum Novitates 2708: $1-20$.

Myers, C. W and J. E. Cadle. 2003. On the snakes hemipenis, with notes on Psomophis and techniques of eversion: a response to Dowling. Herpetological Review 34: 295302.

Palacios-Aguilar, R. and O. Flores-Villela. 2018. An updated checklist of the herpetofauna from Guerrero, Mexico. Zootaxa 4422: 1-24.

Palacios-Aguilar, R. and O. Flores-Villela. 2020. Taxonomic revision and comments on two groups of the genus Coniophanes (Squamata: Dipsadidae). Vertebrate Zoology 70: 111-124.

Pavón-Vázquez, C. J., U. O. García-Vázquez, J. C. BlancasHernández, and A. Nieto-Montes de Oca. 2011. A new species of the Geophis sieboldi (Squamata: Colubridae) exhibiting color pattern polymorphism from Guerrero, Mexico. Herpetologica 67: 332-343.

Savage, J. M. and P. T. Lahanas. 1991. On the species of the colubrid snake genus Ninia in Costa Rica and Western Panamá. Herpetologica 47: 37-53.

Smith, E. N. and J. A. Ferrari-Castro. 2008. A new species of jumping pitviper of the genus Atropoides (Serpentes: Viperidae: Crotalinae) from the Sierra de Botaderos and the Sierra La Muralla, Honduras. Zootaxa 1948: 57-68.

Zaher, H. and A. L. C. Prudente. 2003. Hemipenis of Syphlophis (Serpentes, Xenodontinae) and techniques of hemipenial preparation in snakes: a response to Dowling. Herpetological Review 34: 302-307.

Editor: Ross D. MacCulloch 